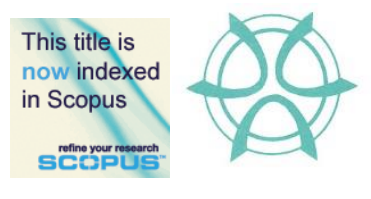

PLANNING MALAYSIA:

Journal of the Malaysian Institute of Planners

VOLUME 17 ISSUE 2 (2019), Page 112 - 122

\title{
QUANTIFYING THE ORGANIC WASTE GENERATED FROM THE FRESH MARKET IN KUNDASANG TOWN, SABAH
}

\author{
Nurul Nadia Fatiha Yaacob ${ }^{1}$, Latifah Abd Manaf ${ }^{2}$ \\ \& Zulfa Hanan Ash'aari ${ }^{3}$ \\ ${ }^{1,2,3}$ Faculty of Environmental Studies \\ UNIVERSITI PUTRA MALAYSIA
}

\begin{abstract}
It is necessary to assess solid waste generation to identify the rate by which we generate waste. A rapid increase in solid waste generation constitutes a significant challenge for developing countries such as Malaysia. Municipal Solid Waste (MSW) is the primary source of solid waste generated in Malaysia and covers $64 \%$ of the total waste composition. $45 \%$ of the average composition of Malaysian MSW is dominated by organic waste (e.g. food, vegetable and fruits). This is followed by recyclable waste (e.g. plastic, paper and metal) at $30 \%$ with the remaining made up of non-recyclable waste (e.g. polystyrene). The Fresh Market in Kundasang town, Sabah is a major contributor to the increase of organic waste generated in the Ranau district. As such, it has the potential to implement effective composting practices. This study was conducted to determine the total amount of organic waste generated as well as the organic waste generation rate in the Fresh Market. The sampling was conducted among 148 sellers in the Fresh Market over a period of two weeks $\left(5^{\text {th }}\right.$ August $-18^{\text {th }}$ August 2017). Total organic waste generation was $13,147.50 \mathrm{~kg}$, while the organic waste generation rate was $6.35 \mathrm{~kg} / \mathrm{premise} / \mathrm{day}$. The value for municipal solid waste generation recorded by Majlis Daerah Ranau (MDR) in three varied routes of Kundasang during August 2017 (Jalan Pekan Kundasang, Jalan Mesilou and Jalan Kota Kinabalu) were 17 tonnes, 15 tonnes and 13 tonnes respectively. This shows that the solid waste generated in Jalan Pekan Kundasang was the highest compare to Jalan Mesilou and Jalan Kota Kinabalu. This study presents the current status of organic waste generation which can serve as preliminary baseline information.
\end{abstract}

Keywords: compost; municipal solid waste; organic waste; waste generation; waste composition 
PLANNING MALAYSIA

Journal of the Malaysia Institute of Planners (2019)

\section{INTRODUCTION}

Increased generation of solid waste and its management represents a significant challenge for Malaysia. Currently, the mean per person of solid waste generation in Malaysia is $0.85 \mathrm{~kg} /$ person/day and an estimated 33,130 tonnes of solid waste per day is generated, thereby exceeding the projected production of 33,000 tonnes per day by 2020 (Mohammed, Mustafa, Bashir, \& Mokhtar, 2013). The composition of solid waste in Malaysia is dominated by recyclable waste, but these wastes are not fully recovered and recycled. The percentage of organic waste is the highest consisting of up to $63.7 \%$ of the total solid waste composition found in landfill sites. These organic wastes contain high moisture content, and the bulk density is above $200 \mathrm{~kg} / \mathrm{m}^{2}$ (Sumiani, Onn, Mohd, \& Wan, 2009).

Malaysia has undergone substantial change in agricultural exports for all five regions; the Northern, Central, Southern, East Coast and Eastern with an estimated population of 8,250 involved in vegetable production (Tey et al., 2014). A highland altitude is a suitable place for the growth of temperate crops throughout the year. In Peninsular Malaysia, farmers grow their temperate vegetables, fruits, flowers and also tea in Cameron Highland due to its conducive climate (Saadati, Abdullah, Zakaria, Rezayi, \& Hosseinizare, 2012). Meanwhile, in Sabah, temperate vegetables and fruits are grown in Kundasang. Most of these vegetables and fruits are produced by smallholder farmers to fulfil the demand of local community members and/or tourists. Wholesale traders then buy these agricultural products from the Fresh Market in Kundasang town. This Fresh Market contains small stalls selling a variety of fresh food such as vegetables and fruit.

In Sabah, an estimated 1.4 million tonnes of solid waste was generated, and the volume is increasing rapidly (Ministry of Housing and Local Government, 2013). Kundasang is the most-visited destination in Sabah by both local and international tourists due to its proximity to Mount Kinabalu (the highest mountain in Southeast Asia). Increased tourist numbers and rapid economic development have led to significant increases in the volume of solid waste being generated in this area. Additionally, most wholesale vegetables from Sandakan (east coast) and Kota Kinabalu (west coast) are sent directly to Kundasang. As such, Kundasang is regarded as a regional hub for fresh produce distribution due to its strategic geographic location and accessibility. The roads linking Kota Kinabalu, Kundasang and Sandakan, are among the first paved roads to be built in Sabah and were completed in 1972 (Dambul \& Buang, 2017).

The recent rapid expansion of agriculture production in this area has also led to increased generation of organic waste. These organic waste materials need to be managed sustainably to avoid the depletion of natural resources, minimise risk to human health, reduce environmental burdens and maintain an overall balance in the ecosystem. One method of archiving this is by composting as it is low-cost and environmentally-friendly. According to Agamuthu, Khidzir and 
Nurul Nadia Fatiha Yaacob, Latifah Abd Manaf \& Zulfa Hanan Ash'aari

Quantifying of Organic Waste Generation from Fresh Market, Kundasang Town, Sabah.

Hamid (2009), in order to structure a proper solid waste (SW) management practice for a given region, it is essential to know the quantity of waste generated and its composition before any implementation process can take place.

Thus, this study aims to determine the total amount of organic waste production together with organic waste generation rates (waste generation per premise) in the Fresh Market in Kundasang town, Sabah. The data were obtained to identify the majority of the organic waste generation rates by the sellers in the Fresh Market. The study provides preliminary baseline information for the decision-making stage for planning and management plans.

\section{RESEARCH BACKGROUND}

This study was conducted at Kundasang, located in the Sabah highlands. It is among the most popular tourist destinations in Sabah because of its proximity to Mount Kinabalu. Historically, Kundasang is a rural area, which has grown from a small town into a popular leisure destination for visitors from all over the world. As a result, the area has experienced increased development of resorts and homestay accommodation making tourism the main activity in Kundasang with most of the villagers working as farmers and/or sellers of fresh vegetables at the small stalls in Kundasang town. However, the tourism activities have affected the environment as rising consumption has increased municipal solid waste generation, especially organic waste.

The total agricultural area in Kundasang is $18,085.2$ hectares. It is experiencing continuous growth in agricultural activities (Roslee, Tahir, Musta \& Omang, 2010). The Fresh Market in Kundasang is located between Mount Kinabalu and Ranau town (six kilometres from the southeast side of Mount Kinabalu and 12 kilometres from Ranau town). The Fresh Market houses 235 sellers who operated from small stalls selling vegetables and fruits. These stalls contribute to the production of large amounts of organic waste. The typical seller is a mature adult woman aged between 40 to 59 years. Business operations extend from $7 \mathrm{am}$ to $6 \mathrm{pm}$ (Monday to Saturday). Figure 1 shows the location of the Fresh Market.

\section{METHODOLOGY}

This study focuses on the issue of organic waste generated by the vegetable and fruit sellers in the Fresh Market. According to the Malaysian Standards MS2505:2012, solid waste generation includes waste retained for other purposes and wastes discarded for collection. This refers to direct waste collection either at the source (e.g. individual premises) and/or from vehicle loads (Edjabou et al., 2015). This is a quantitative research using the direct measurement of organic waste, as summarised in Figure 2. 
PLANNING MALAYSIA

Journal of the Malaysia Institute of Planners (2019)

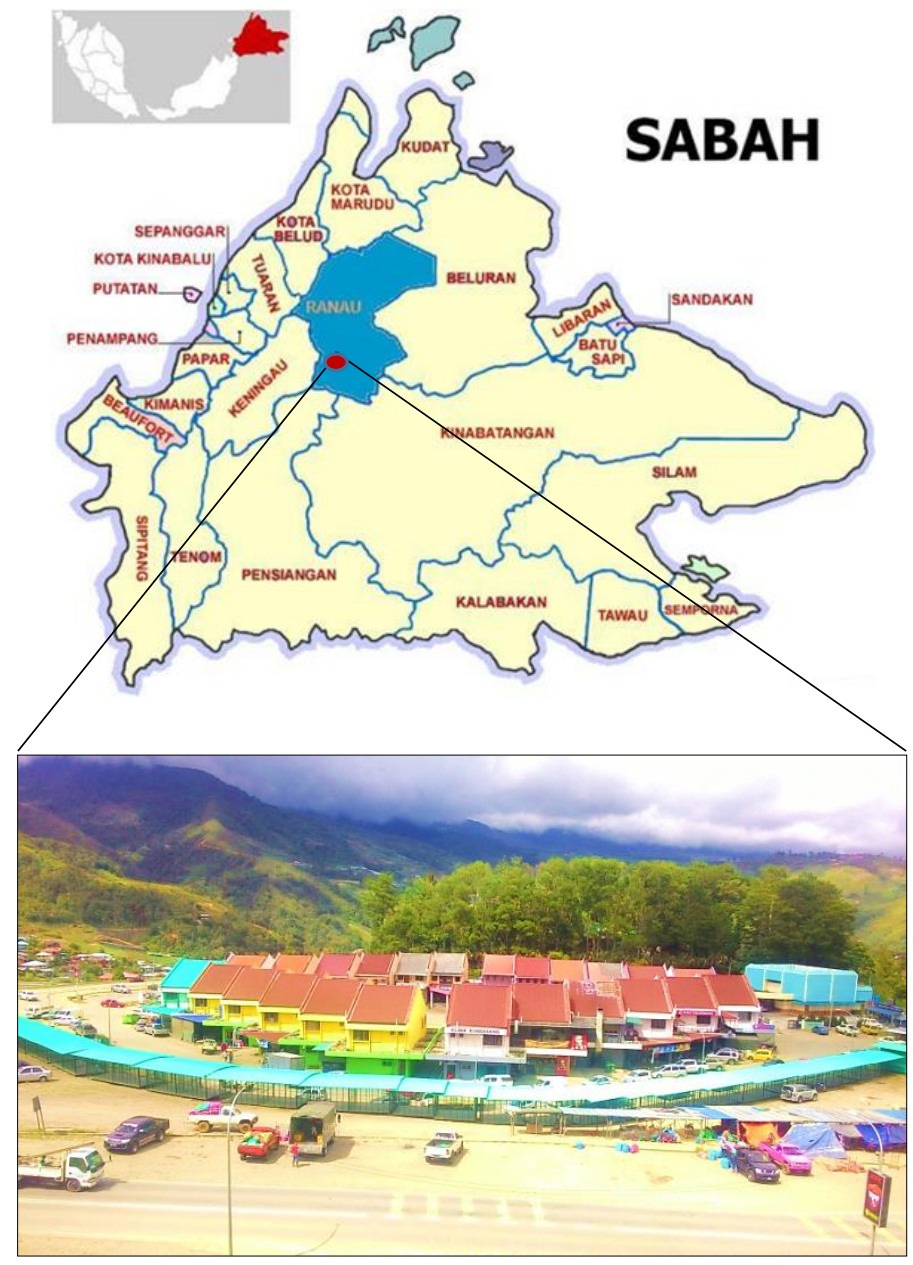

Figure 1 Fresh Market, Kundasang town

\section{Organic Waste}

According to the Malaysian Standards (2012), there are 15 components of solid waste. Only six components out of the 15 are usually sufficient for a general solid waste study, specifically: organic waste; paper; plastic; glass; metal/aluminium and others. This study measures organic waste as the highest percentage of solid waste generated in the Fresh Market. Tchobanoglous, Theisen and Vigil (1993) state that organic waste comprises vegetable peelings and trimmings, as well as fruits and can also include cooked vegetables. This includes kitchen waste that contains or is potentially contaminated with meat or meat products. 
Nurul Nadia Fatiha Yaacob, Latifah Abd Manaf \& Zulfa Hanan Ash'aari

Quantifying of Organic Waste Generation from Fresh Market, Kundasang Town, Sabah.

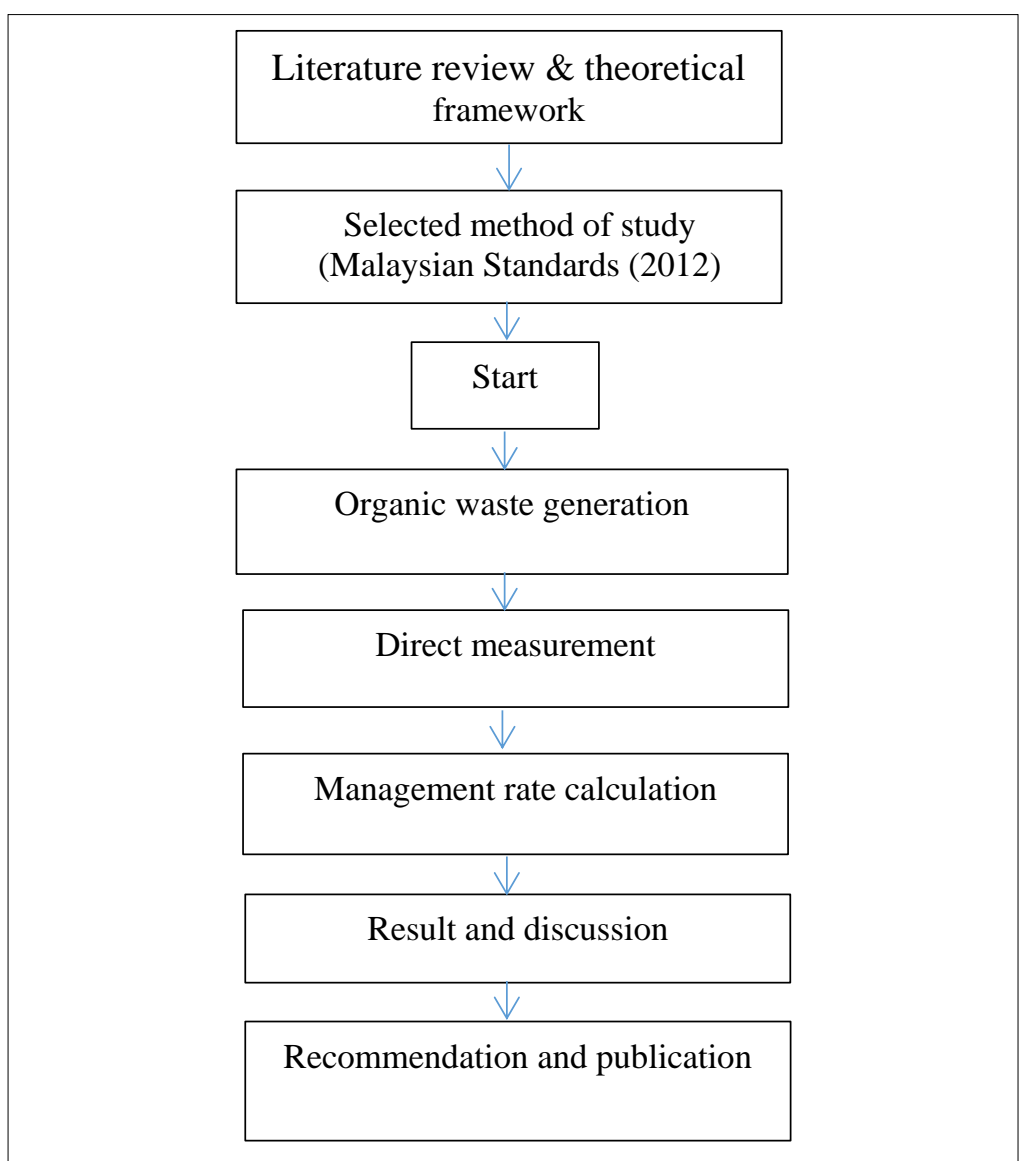

Figure 2 Methodological Framework

\section{Equipment}

The two items of equipment used when measuring organic waste generation are weighting scale $(\mathrm{kg})$ and plastic bags. Table 1 briefly explains the function of this equipment.

\section{Waste Sampling}

Sampling of organic waste was conducted in Fresh Market, Kundasang town for a period of 14 days (two weeks). There were 148 respondents from a total of 235 sellers who were randomly selected based on the formula of sample size by Yamane (1967). An appropriate sample size for this study at $90 \%$ confidence level is shown in Equation (1). 
PLANNING MALAYSIA

Journal of the Malaysia Institute of Planners (2019)

Table 1 List of equipmen

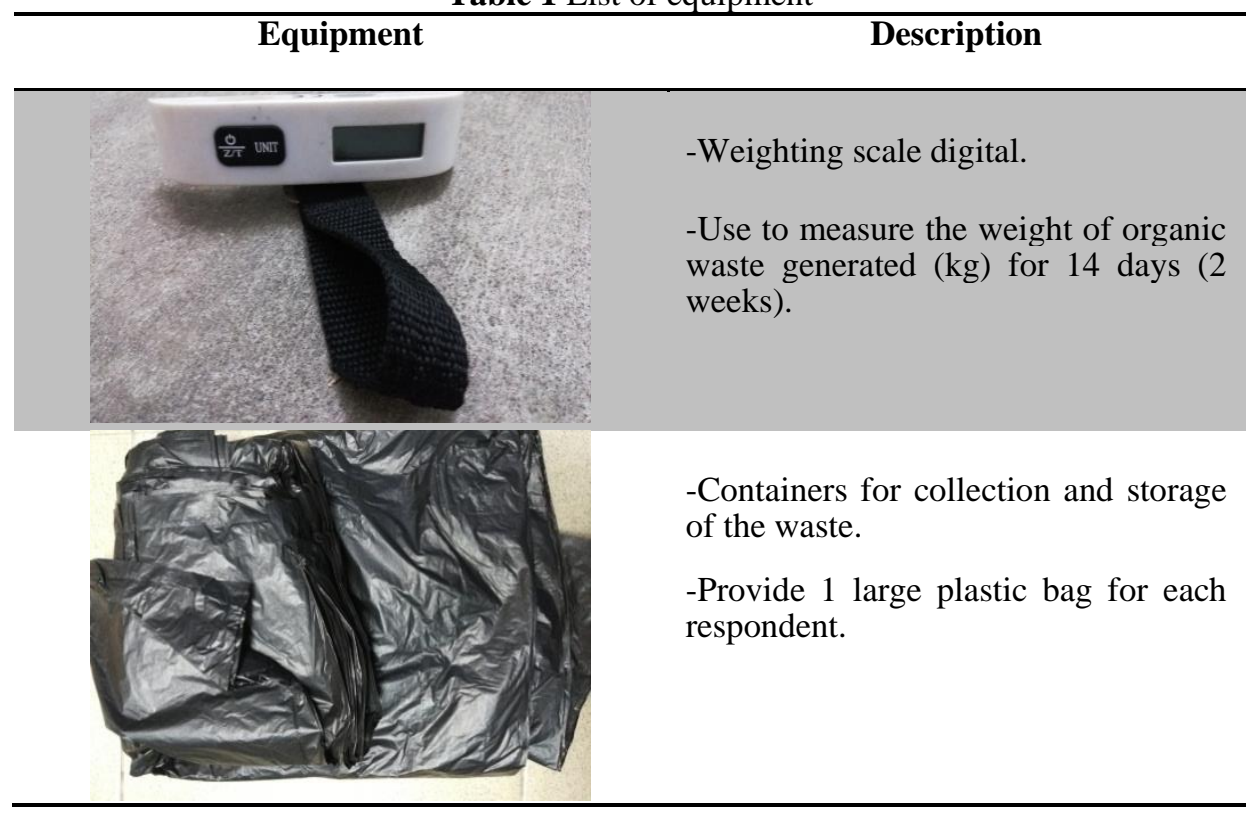

$\mathrm{n}=\mathrm{N} /\left(1+\mathrm{Ne}^{\wedge} 2\right)$ Equation (1)

Where;

$\mathrm{n}=$ sample size

$\mathrm{N}$ = population size (no of premises)

$\mathrm{E}=$ level of precision $($ constants $=0.05)$

The selected vegetable and fruit sellers were given plastic garbage bags to collect the organic waste which was weighed and recorded daily. Figure 3 shows the flowchart of the organic waste sampling activities.

\section{Data Calculation}

The organic waste generation rate was calculated using Equation (2) to identify the amount of organic waste produced daily. Meanwhile, the percentage of organic waste is calculated using Equation (3) to determine the percentage of organic waste from the total solid waste generated by the sampled sellers. The secondary data for municipal solid waste generated was recorded by MDR in three varied routes during August 2017 as shown in Table 2. 
Nurul Nadia Fatiha Yaacob, Latifah Abd Manaf \& Zulfa Hanan Ash'aari

Quantifying of Organic Waste Generation from Fresh Market, Kundasang Town, Sabah.

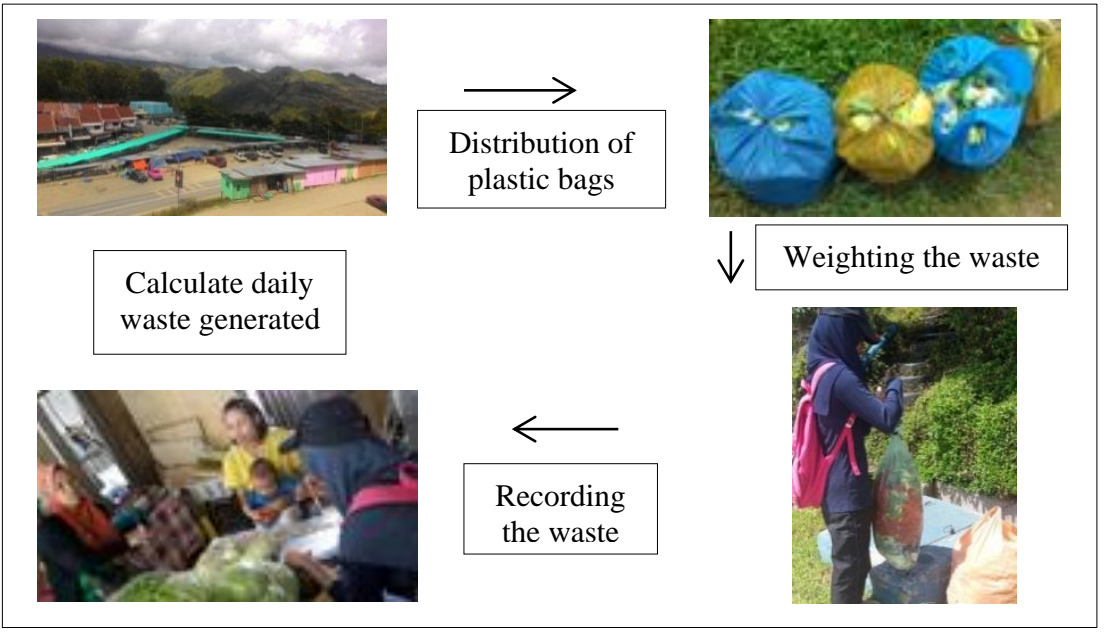

Figure 3 Flowchart for measuring organic waste

Table 2 Municipal solid waste generated in August 2017

\begin{tabular}{cc}
\hline Location & Municipal solid waste (tonnes) \\
\hline Jalan Pekan Kundasang & 17 \\
Jalan Mesilou & 15 \\
Jalan Kota Kinabalu & 13 \\
\hline
\end{tabular}

Rate of waste genaration $=\frac{\text { organic waste weight }(\mathrm{kg})}{\text { no.of stall } \mathrm{x} 14 \text { day }} \ldots$ Equation $(2)$

Organic waste $\%=\frac{\text { Organic waste weight }(\mathrm{kg})}{\text { total municipal solid waste weight }(\mathrm{kg})} \times 10 \ldots$ Equation (3)

\section{RESULTS AND DISCUSSION}

The organic waste generated by small stalls from Fresh Market in Kundasang town is shown in Table 3. The total organic waste generation over a period of two weeks was $13,147.50 \mathrm{~kg}$. The waste generation rate was expressed in $\mathrm{kg}$ per stall per day and was estimated at $6.35 \mathrm{~kg}$. The Fresh Market in Kundasang plays an important role in providing fresh agro-products for surrounding communities. The organic waste generation rate was high compared to the solid waste generation rate in the range of $0.5-0.8 \mathrm{~kg} / \mathrm{capital} / \mathrm{day}$ for Malaysia. Another factor that contributes to the high amount of organic waste is because these wastes are disposed directly into landfills and are not composted or converted into animal feed which is more environmentally sustainable. Agamuthu and Fauziah (2007) suggest that the establishment of new technology in the manufacturing of animal feed with desired nutrient levels has rendered organic market waste no longer viable as the source of food for animals. Most studies found that organic waste 
PLANNING MALAYSIA

Journal of the Malaysia Institute of Planners (2019)

was the predominant factor in MSW fraction, although the percentage of organic waste varied considerably (Wagland, Veltre, \& Longhurst, 2012).

Table 3 Organic waste generation in Fresh Market, Kundasang town

\begin{tabular}{ccc}
\hline $\begin{array}{c}\text { Organic } \\
\text { waste } \\
\text { (vegetable }\end{array}$ & $\begin{array}{c}\text { Waste generation } \\
(\mathbf{k g})\end{array}$ & $\begin{array}{c}\text { Generation rate } \\
\text { (kg/person/day) }\end{array}$ \\
\cline { 2 - 3 } and fruits) & $13,147.50$ & 6.35 \\
\hline
\end{tabular}

The frequency of organic waste generation rate for sellers at Fresh Market is shown in Figure 4 over a period of 14 days. In this study, the majority of respondents (113) generated less than $5.00 \mathrm{~kg} /$ person/day, followed by six respondents who generated in the range of 6.00 to $10.0 \mathrm{~kg} / \mathrm{person} / \mathrm{day}$. However, 13 respondents generated less than $20.00 \mathrm{~kg} / \mathrm{stal} / \mathrm{day}$. Besides that, 12 respondents generated below $30.00 \mathrm{~kg} / \mathrm{stall} / \mathrm{day}$, while only four respondents generated above $30.00 \mathrm{~kg} / \mathrm{stall} /$ day in this study. Thus, sellers mostly generated less than $5.00 \mathrm{~kg} / \mathrm{stall} / \mathrm{day}$ (when taking into account the representative size of the stall).

The trend of organic waste generation for sellers in the Fresh Market is shown in Figure 5 over a period of 14 days. The generation of organic waste was highest on 15 August $(4,157.10 \mathrm{~kg})$, followed by 14 August and 16 August with rates of 2,682.30 kg and 2,608.20 kg respectively. This occurred because, during that time, most of the vegetables (especially Napa Cabbage and cauliflower) are widely produced. At this time, the sellers receive triple the number of agricultural products compared to a normal day. These vegetables and fruits are processed and packaged by the sellers before being sold to customers. However, unwanted parts from these vegetables (such as leaves and roots) are discarded as waste. Most of this waste will then be collected and transported to the landfill site by MDR (the local authority). This event is commonly known as the flood season, or 'musim banjir', and refers to peak production of agricultural product in Kundasang. 
Nurul Nadia Fatiha Yaacob, Latifah Abd Manaf \& Zulfa Hanan Ash'aari

Quantifying of Organic Waste Generation from Fresh Market, Kundasang Town, Sabah.

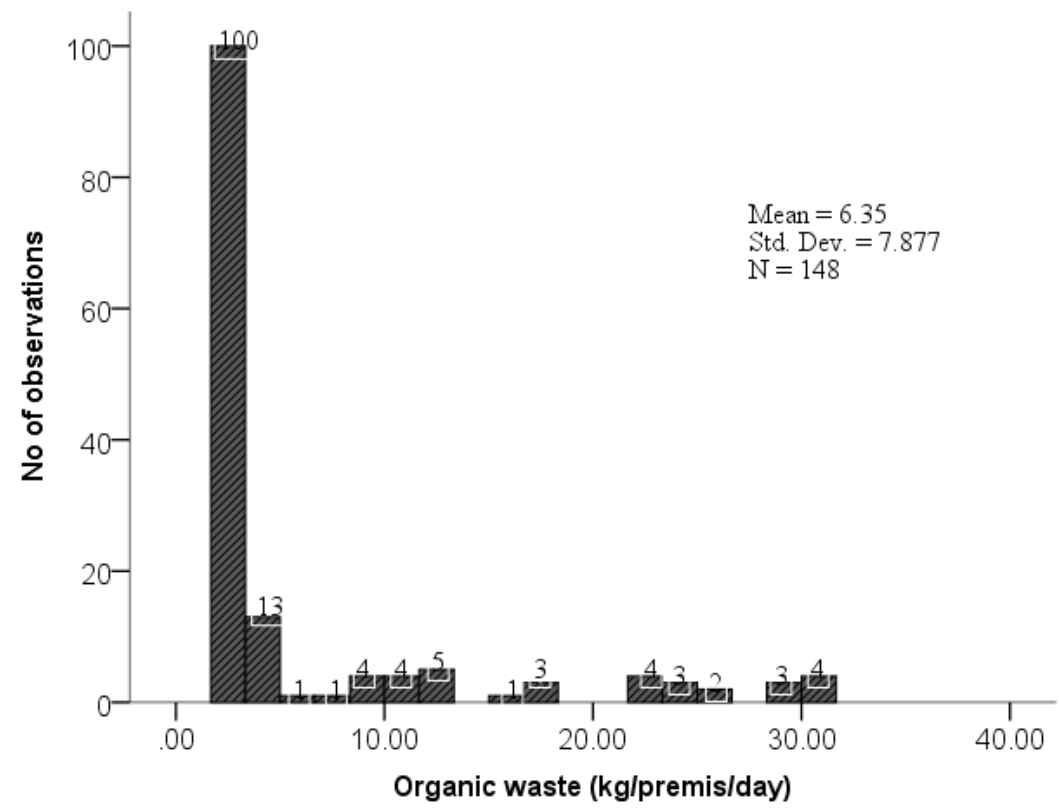

Figure 4 Frequency of organic waste generation of sellers per day

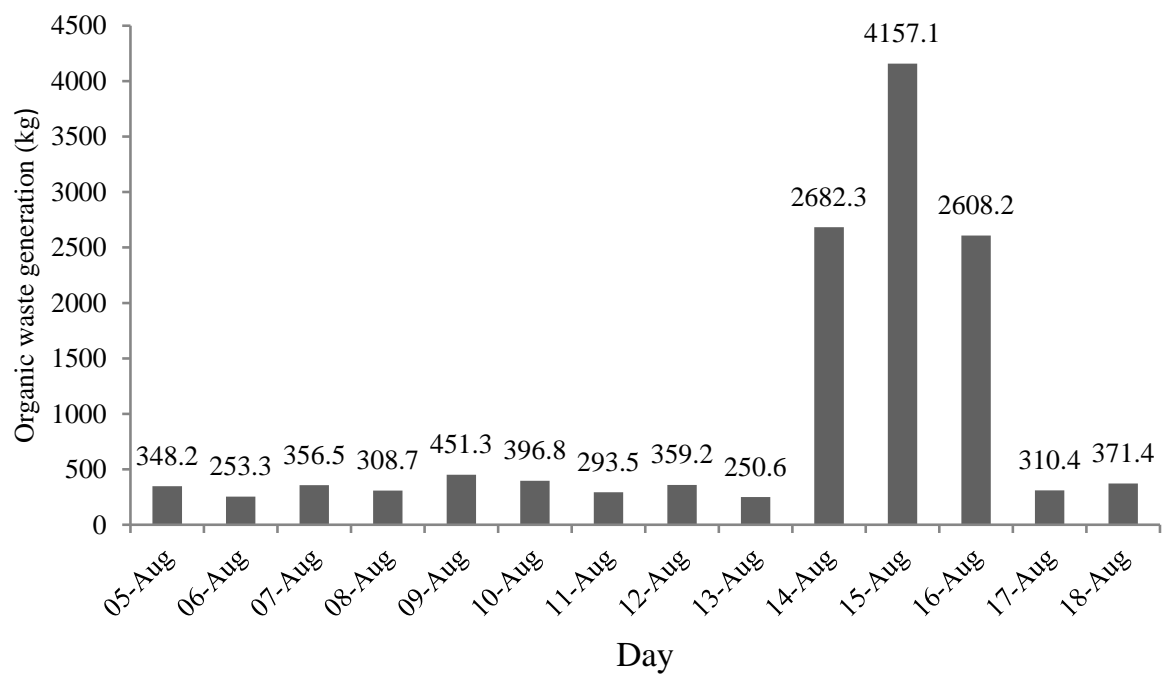

Figure 5 Trend of organic waste generation

The total percentage of organic waste and MSW is shown in Figure 6. The secondary data for municipal solid waste was obtained through the number of vehicles that transport these waste materials to the landfill site in Tanah Merah, 
PLANNING MALAYSIA

Journal of the Malaysia Institute of Planners (2019)

Ranau. The highest solid waste recorded (17 tonnes) was collected from Pekan Kundasang, followed by Jalan Mesilou (15 tonnes). The lowest amount of solid waste (13 tonnes) was collected from Jalan Kota Kinabalu. 77\% from the total municipal solid waste was organic waste, while $23 \%$ was in the category of "other" including recyclable and non-recyclable waste. These findings determine that solid waste generation is dominated by organic waste as a result of high demand for vegetables and fruit from the local community and/or tourists. This study also shows that the Fresh Market generated a large amount of municipal solid waste compared to Jalan Mesilou and Jalan Kota Kinabalu. Thus, it is essential to promote composting activities among the sellers to reduce the amount of organic waste.

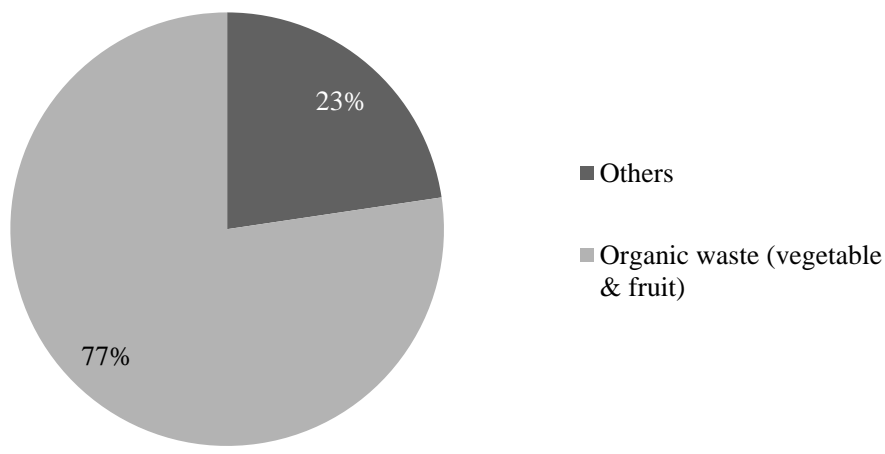

Figure 6 Percentage of organic waste from MSW in Kundasang town

\section{CONCLUSION}

Based on the data analysis, the amount of solid waste generated in the Fresh Market Kundasang is higher compared to that of Jalan Kota Kinabalu and Jalan Mesilou. This can be attributed to huge amounts of organic waste produced. This indicates that waste generated in Kundasang is largely dominated by organic waste compared to others. Hence, the composting of organic waste is the best type of solid waste management practice for this area. As such, we propose that the local authority (MDR) should conduct suitable composting workshops for the benefit of sellers in the Fresh Market as a preliminary step towards reducing the production of organic waste.

\section{ACKNOWLEDGEMENTS}

The authors express their gratitude to the Pusat Pengurusan Penyelidikan, UPM for financing this study via the GP-IPS grant. They also acknowledge Majlis Daerah Ranau (MDR) for providing the data and the information used in this research. 
Nurul Nadia Fatiha Yaacob, Latifah Abd Manaf \& Zulfa Hanan Ash'aari

Quantifying of Organic Waste Generation from Fresh Market, Kundasang Town, Sabah.

\section{REFERENCES}

Agamuthu, P., \& Fauziah, S. H. (2007). Sustainable management of wet market waste. In Proceedings of the International Conference on Sustainable Solid Waste Management (pp. 5-7). Centre for Environmental Studies, Department of Civil Engineering, Anna University.

Agamuthu, P., Khidzir, K. M., \& Hamid, F. S. (2009). Drivers of sustainable waste management in Asia. Waste Management \& Research, 27(7), 625-633.

Dambul, R. D., \& Buang, A. (2017). Memahami permasalahan pelancongan di Kundasang, Sabah: Kekuatan dan kelemahan pendekatan positivisme (Explaining the problems of tourism in Kundasang, Sabah: The strengths and limitations of the positivist perspective). Geografia-Malaysian Journal of Society and Space, 4, 20-31.

Edjabou, M. E., Jensen, M. B., Götze, R., Pivnenko, K., Petersen, C., Scheutz, C., \& Astrup, T. F. (2015). Municipal solid waste composition: Sampling methodology, statistical analyses, and case study evaluation. Waste Management, 36, 12-23.

Ministry of Housing and Local Government. (2013, October 15). Statistic on average of solid waste generation in each state. Available at http://www.kpkt.gov.

Mohammed, Y. S., Mustafa, M., Bashir, N., \& Mokhtar, A. S. (2013). Renewable energy resources for distributed power generation in Nigeria: A review of the potential. Renewable and Sustainable Energy Reviews, 22, 257-268.

Roslee, R., Tahir, S., Musta, B., \& Omang, A. K. (2010). Geological inputs for Landslide Hazard Identification (LHI) in the Trusmadi formation slopes, Sabah, Malaysia. Borneo Science, 26, 37-51.

Saadati, N., Abdullah, M. P., Zakaria, Z., Rezayi, M., \& Hosseinizare, N. (2012). Distribution and fate of $\mathrm{HCH}$ isomers and DDT metabolites in a tropical environment-case study Cameron Highlands-Malaysia. Chemistry Central Journal, 6(1), 130.

Sumiani, Y., Onn, C. C., Mohd, D., \& Wan, W. Z. (2009). Strategies for planning of optimum landfill sitting decision-making. Journal of Sains Malaysiana, 457462.

Tey, Y. S., Li, E., Bruwer, J., Abdullah, A. M., Brindal, M., Radam, A., \& Darham, S. (2014). The relative importance of factors influencing the adoption of sustainable agricultural practices: A factor approach for Malaysian vegetable farmers. Sustainability Science, 9(1), 17-29.

Tchobanoglous, G., Theisen, H., \& Vigil, S. (1993). Integrated solid waste management engineering principles and management issues. Singapore: McGraw-Hill, Inc.

Wagland, S. T., Veltre, F., \& Longhurst, P. J. (2012). Development of an image-based analysis method to determine the physical composition of a mixed waste material. Waste Management, 32(2), 245-248.

Yamane, T. (1967). Statistics: An introductory analysis (2nd Edition). New York: Harper and Row

Received: $12^{\text {th }}$ January 2019. Accepted: $2^{\text {nd }}$ August 2019 